\title{
Geologisk modellering - Sahmah-skiferens petroleumssystemer
}

Af geolog Nick Svendsen, Mcersk Olie og Gas $A S$

Prospektering efter olie er nu om stunder blevet en avanceret proces, hvor man blandt andet bruger computerprogrammertil simulering af de geologiske processer. Det er vigtigt at kunne forstå kulbrinternes vej fra kildebjergarten og frem til, at de bliver fanget i reservoirbjergarten. Hvorvidt processen bliver simuleret korrekt i hver detalje er et åbent spørgsmål, men vi har i alt fald ikke bedre redskaber.

Denne artikel beskriver et eksempel på en simulering, der viser nogle af de arbejdsgange, som en oliegeolog bruger.

Artiklen er desuden en fortsættelse af beskrivelsen afOmans geologi, som indledtes med beskrivelsen af Natih-feltet i 2003.

\section{Bassinmodellering}

Inden for de seneste 10 til 15 år er der udarbejdet computerprogrammer, der kan simulere petroleumssystemer ved hjælp af computere.

Simuleringerne kan være 1D (simulering af en enkelt boring), 2D (simulering af et tværsnit) eller 3D (simulering af et helt bassin eller dele af et bassin)

Den geologiske model, der ligger til grund for simuleringen, skal naturligvis være realistisk, men kan ikke blive bedre en de data, der er til rådighed. Det er derfor vigtigt, at det traditionelle geologiske arbejde først udføres i detaljer og lægges til grund for inputtet til simuleringen.

Fordelene ved at foretage bassinmodellering er, at det tvinger geologen til at indsamle og vurdere data systematisk. Geologen er desuden tvunget til at tage stilling til problemer, han eller hun måske ved en traditionel vurdering ville have ladet ligge. Mangelfulde data eller områder uden data skal vurderes ved kvalificerede gæt. Det er ikke nok at farve en del af bassinet hvidt med et spørgsmålstegn. Det gør selvfølgelig simuleringerne usikre, men så kan man foretage sensitivitetssimuleringer for at kvantificere usikkerheden.

En arbejdsgang for en bassinmodellering kunne se således ud:

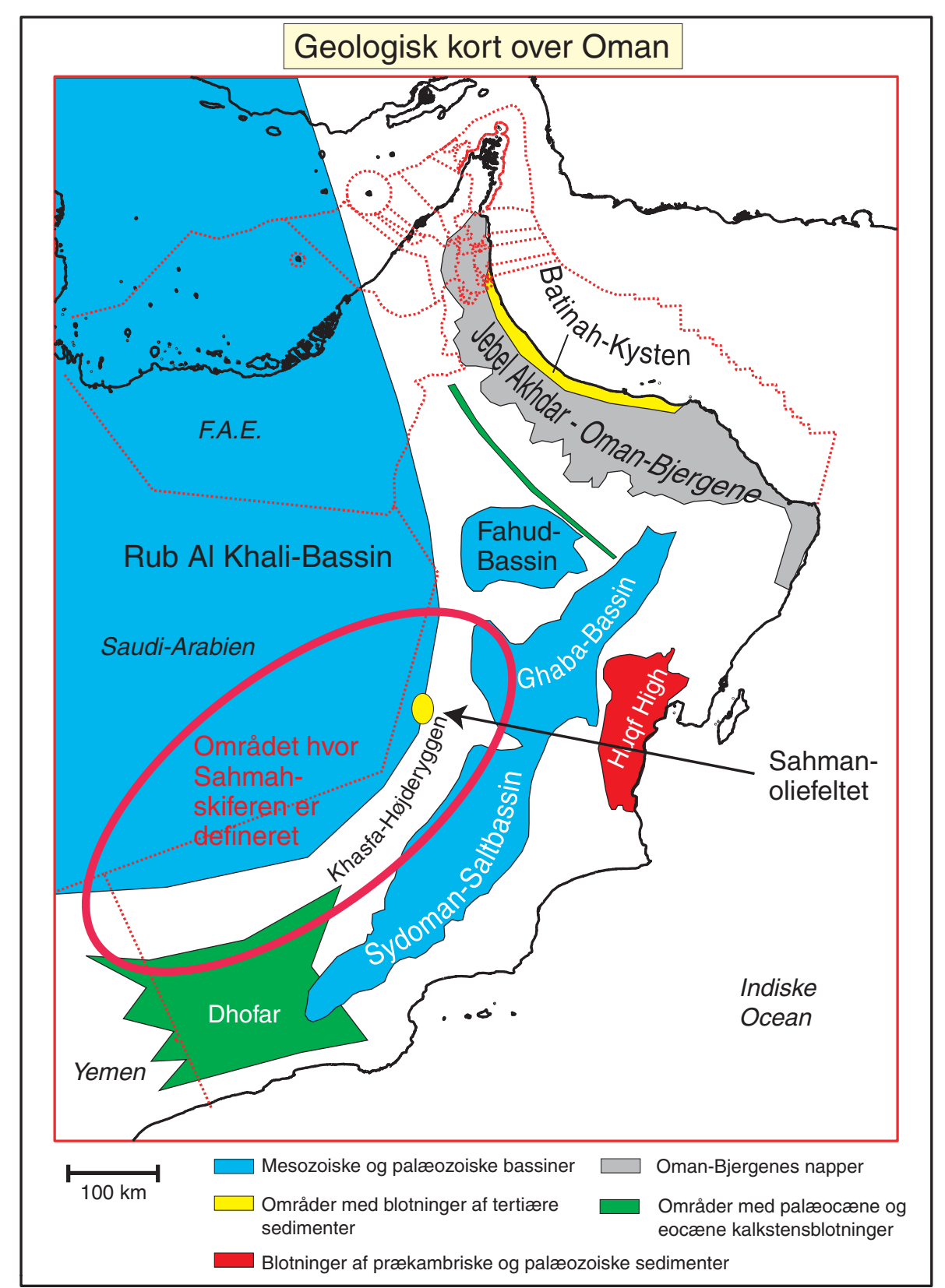

Oversigtskort over de strukturelle elementer i Oman og omkringliggende lande. (Grafik: Forfatteren)

1. Definering af bassinets udstrækning og dets strukturelle elementer.

2. Stratigrafi

3. Strukturel historie

4. Facies for de individuelle sekvenser.

5. Struktur- og tykkelseskort for sekvenserne.

6. Identificering af reservoir og karakterisering af samme.

7. Identificering af forseglingslag og karakterisering af samme.

8. Identificering af kildebjergarter og karakterisering af samme.

9. Kalibrering af bassinmodellen til temperatur samt kildebjergartens modenhedsdata.

10. Simulering.

11. Eventuelle justeringer og iterationer af modellen.

12. Det endelige resultat. 
Processen er iterativ; det er som regel nødvendigt at lave flere sensitivitetskørsler, før man har et resultat, man er tilfreds med. Modellens raffinering er også en funktion af den database, der er til rådighed. Jo større og bedre database jo flere detaljer kan man få ud af simuleringen.

Det skal dog huskes, at en simpel model også kan give den nødvendige basis for en prospektivitetsvurdering.

\section{Petroleumssystemer}

Inden vi fortsætter, må vi definere begrebet petroleumssystem.

Et petroleumssystem er en forekomst af en aktiv kildebjergart med alle de dannede olie- og gasforekomster, som relaterer til den aktive kildebjergart. Det inkluderer ligeledes alle de geologiske elementer og processer, der er essentielle for ovennævnte kulbrinteforekomster.

I det følgende gives et eksempel på en bassinmodellering af Sahmah-skiferen fra Oman ved hjælp af en serie af 1D-modelleringer.

\section{Bassinets strukturelle elementer}

Området, vi skal se på, ligger i den sydlige udkant af Rub Al Khali-Bassinet (kortet på foregående side), som er beliggende i SaudiArabien og strækker sig ind i den centrale del af Oman.

Denne del betegnes også som KhasfaHøjderyggen og separere Rub Al Khali-Bassinet fra Ghaba saltbassinet og de sydomanske saltbassiner.

\section{Stratigrafi}

Omans stratigrafi er gengivet i til højre. Som det kan ses, er Sahmah Formationen fra sen Ordovicium til Nedre Silur. Sahmah Formationen ligger under den Hercyniske Inkonformitet, hvor de fleste af de silure, devone og karbone bjergarter er eroderet væk i Oman.

\section{Sahmah Formationen}

Sahmah Formationen findes i det centrale og sydlige Oman i det område, der grænser op til Saudi-Arabien (figuren øverst på næste side). Formationen består af en øvre sandet del og en nedre skifret del. Den sandede del består af vekslende lag af sand og skifer aflejret i et kystnært marint miljø. Den fremstår på en GR-log med et takket profil. Den nedre del, kaldet Sahmah-skiferen, er aflejret på dybere vand og fremstår med et glat GR-logprofil. Litologisk er det en sort til dels homogen skifer, som mod toppen kan have tynde sandlag, der er aflejret som turbiditter. De nederste 5 til $10 \mathrm{~m}$ af Sahmah-skiferen har et relativt højt organisk indhold. Denne del er kildebjergarten.

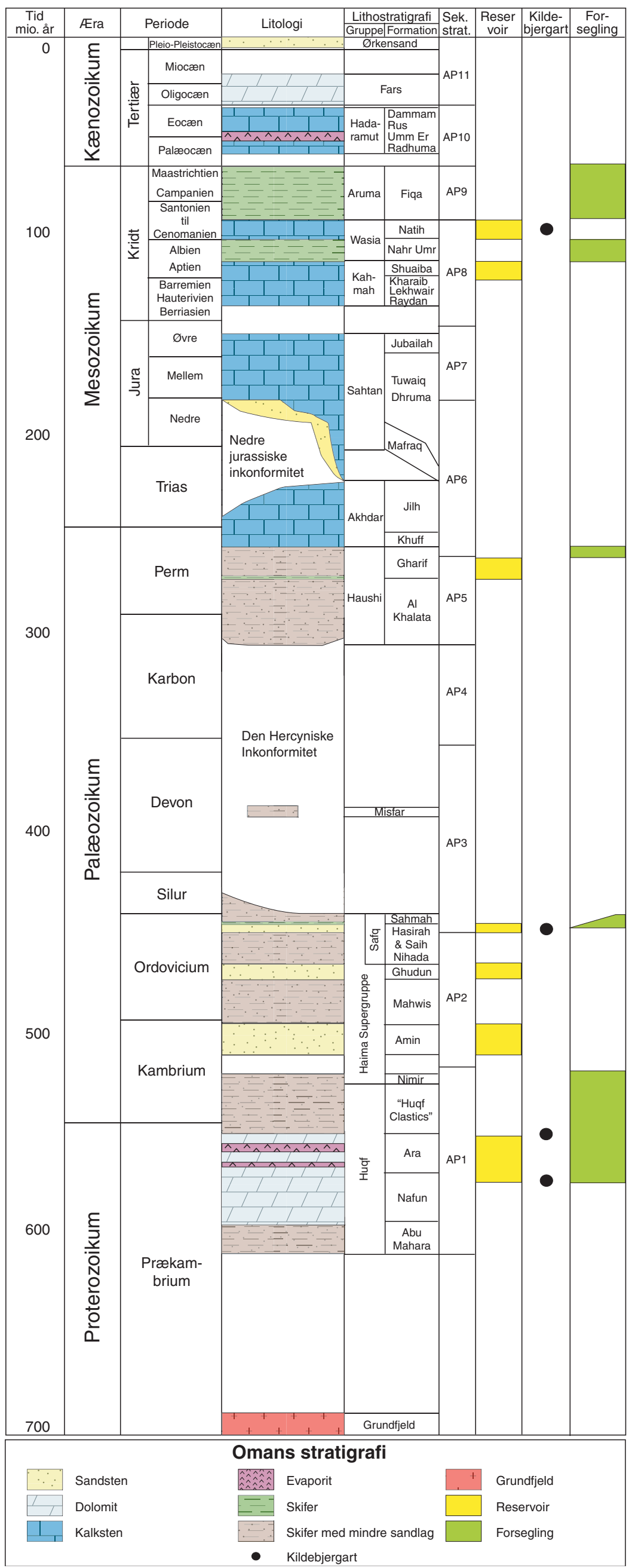




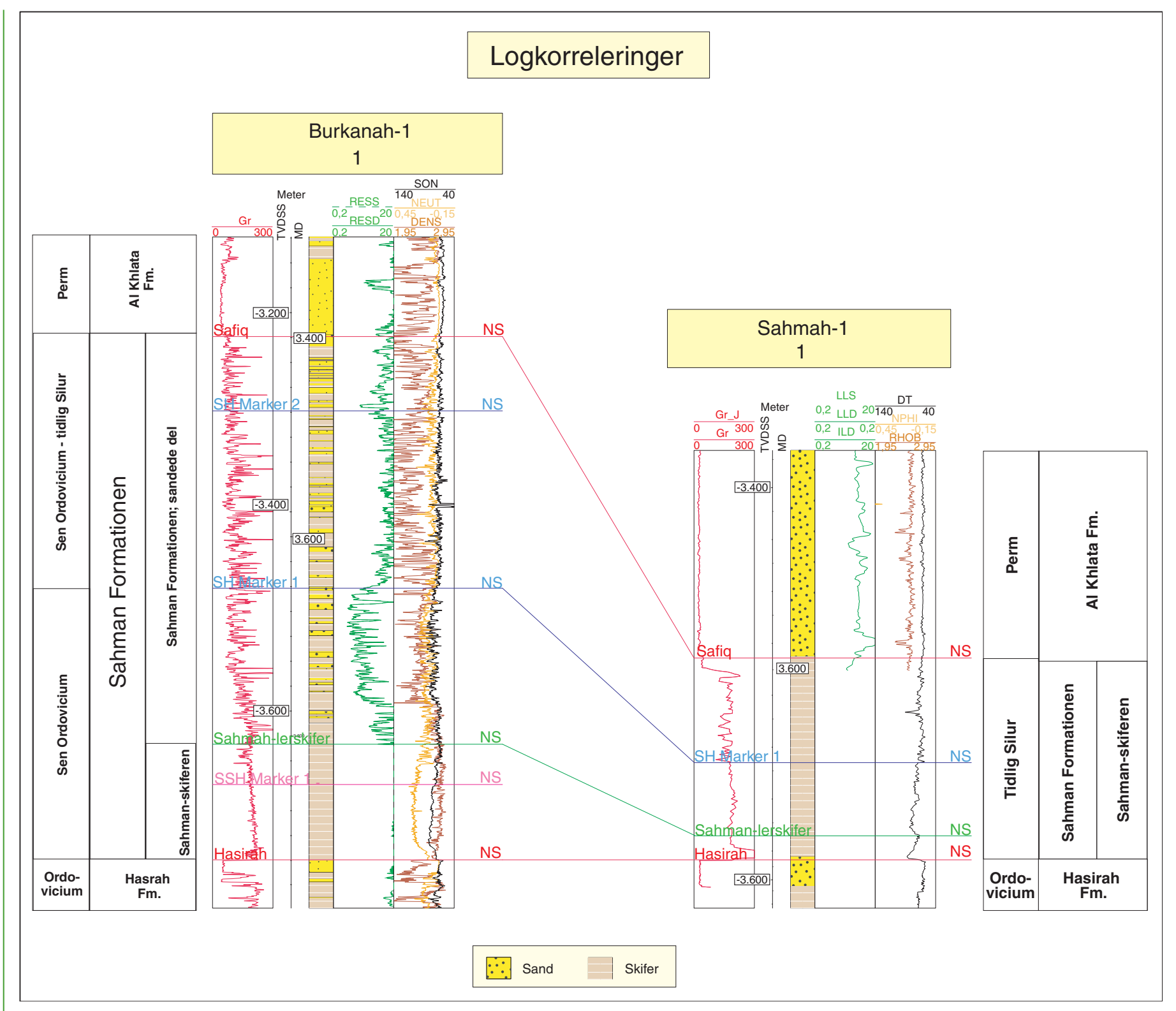

Logkorrelation af Burkanah-1-og Sahmah-1-boringerne for Sahmah-Formationen. Bemork den høje GR-anomali ved basis af skiferen i Sahmah-1-boringen. Korellationen er tildels understøttet af biostratigrafi. Sahmah-skiferen i Sahmah-1 er dateret til tidlig Silur, hvorimod den er dateret til sen Ordovicium i Burkanah-1-boringen. Korrelationen er et forsøg på at løse denne forskel i datering. (Grafik: Forfatteren)

Sahmah Formationen udgør en prograderende marin sekvens, hvor maksimumtransgressionen ("maximum flooding surface") findes i den nederste del af skiferen. Sedimenttilførslen kom fra sydvest, og de enkelte lag i sekvensen er derfor sandede mod sydvest og bliver mere skifrede mod øst og nordøst og samtidigt tyndere. Sahmah Formationen strækker sig i alder fra det øverste Ordovicium (Ashgill) til det tidlige Silur(Llandovery).

Alderen af Sahamah Formationen er omdiskuteret. Oprindeligt blev Formationen defineret i det centrale Oman, men aldersdateringer i Burkanah-1-boringen fra det sydlige Oman antyder, at aflejringen begyndte allerede i sen Ordovicium. Logkorreleringen, som er vist ovenfor, er et forsøg på at forklare den diakrone alder af Sahmah-skiferen.

Sahmah Formationen er delvist ækvivalent til Qusaibah Formationen i Saudi-Ara- bien, som også dér er kendt som en vigtig kildebjegart. Qusaibah Formationen er traditionelt blevet dateret som Nedre Silur.

Den Arabiske Halvø var i Ordovicium en del afGondwana-kontinentet. I Ordovicium lå dette kontinent nede ved Sydpolen, inden det flød mod nord mod ækvator og siden splittedes op. Det vil sige, at klimaet var koldt. Der kendes da også glaciale aflejringer fra det sene Ordovicium i Saudi-Arabien. Sådanne er ikke kendt i Oman, og man må formode, at gletscheren har befundet sig i området, der i dag ligger mod vest og nord i Yemen og Saudi-Arabien. Den nederste del af Sahmah-Formationens bjergarter kan derfor være aflejret i et periglacialt miljø, mens den resterende del af Formationen er fra en periode, hvor gletscherne var smeltet.

\section{Strukturel Historie}

Den tektoniske historie for området er præget af opløft med erosion samt forkastnings- bevægelser i Karbontiden. Nogle steder i Saudi-Arabien er mere end $1.000 \mathrm{~m}$ sedimenter eroderet. I området, vi skal se på, er der dog ingen spor af større forkastningsaktivitet, kun opløft og erosion. Denne erosionsperiode kaldes den Hercyniske Inkonformitet og dækker over perioden fra Silur til Karbon, dvs. ca. 120 millioner år. Hvis vi ser på, hvilke formationer der ligger under inkonformiteten i Oman, er det kambriske og ordoviciske formationer med 
de ældste beliggende mod øst (figuren til højre). Silur kendes fra Saudi-Arabien. Midt ned gennem Oman ligger et bælte af Misfar Formationen, som er fra det mellemste Devon. Det antyder en lidt kompliceret erosionshistorie. Der må være tale om 2 inkonformiteter, en der dækker perioden fra Silur til Mellem Devon, og en der dækker perioden Øvre Devon. Det vides ikke, hvorfor Misfar Formationen er bevaret lokalt og ikke findes overalt. Måske skyldes det en dybere erosion andre steder, eller at formationen kun blev aflejret der, hvor den findes. Da erosionen skærer dybest mod øst, har dette område været udsat for et relativt større opløft end resten af Oman.

Den øverste inkonformitet er relateret til opbrud af Gondwana-kontinentet i flere kontinentplader. På det tidspunkt lå den arabiske plade tæt op ad den indiske plade. Der opstod en rift mellem dem i løbet af Karbon. Inden riften opstod, blev området opløftet og eroderet.

De tertiære, tektoniske begivenheder, der dannede bjergene i Nordoman, har kun $\mathrm{i}$ mindre grad berørt den centrale del af Oman og kun i form af svage folder.

\section{Struktur- og isopachyt-kort}

Denne bassinmodellering er baseret på en serie af 1D-modeller, og det er derfor ikke nødvendigt at fremstille isopachyt- og strukturkort på alle horisonterne. Det havde været nødvendigt ved en 3D-modellering. Der er dog blevet lavet et isopachyt-kort over Sahmah-skiferen, der jo udgør den nederste del af Sahmah Formationen. Det viser, at skiferen er tykkest mod syd dvs. influx af sedimenter fra syd (figuren øverst på næste side.

Strukturkort er ofte baseret på en fortolkning af seismiske data. Der har ikke været muligt at få en seismisk dækning over hele området, og strukturkort ville i høj grad være

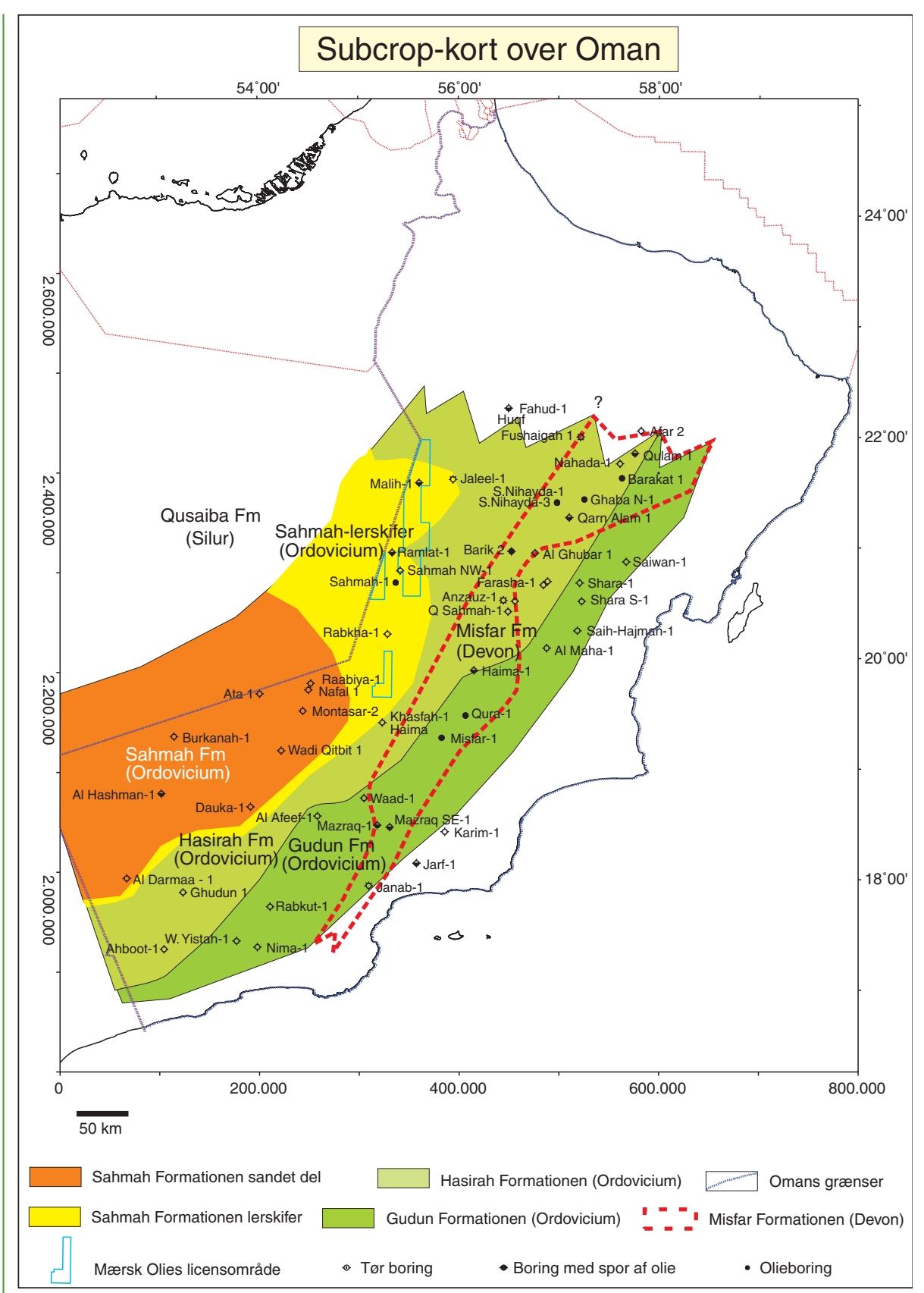

Subcrop-kort over den Hercyniske Inkonformitet for det område, hvor forfatteren har haft adgang til boredata. Inkonformiteten er til stede på stort set hele den Arabiske Halvø. (Grafik: Forfatteren)

baserede på boredata og derfor være af meget generel karakter.

Strukturkort er derfor ikke vist, men de ville være nødvendige for at bestemme retningen af kulbrintemigrationen. I denne artikel er de detaljerede migrationsruter ikke diskuteret, og de ville også være nødvendige i den endelige vurdering af et område.

\section{Reservoir og forsegling}

Det nederste sand i Gharif Formationen udgør udmærkede reservoirer og en hel del af Omans olie produceres da også fra GharifFormationen. De mellemliggende skifre udgør forseglingen.

Under Sahmah-skifren ligger ordovicisk marint sand fra Hasirah-Formationen, som visse steder i Oman udgør et reservoir. Den overligende Sahmah-skiferen udgør forseglingen på reservoir-sandet.
Kildebjergarten og dens udbredelse De nederste ca. $10 \mathrm{~m}$ af Sahmah-skiferen fremstår med en til tider markant GR-loganomali. GR-loggen måler den radioaktive stråling fra bjergarterne, og en bjergart med organisk indhold har ofte et forhøjet indhold af radioaktive mineraler. GR-loganomalien viser derfor, hvor kildebjergarten befinder sig. Det er bekræftet ved geokemiske målinger på boreprøverne fra Sahmah-skiferen. I gennemsnit indeholder kildebjergarten 2 til 3 $\%$ organisk materiale, men der er målt et maksimum på $8 \%$ i en af de nordlige boringer.

Målingerne fra adskillige boringer antyder, at kildebjergarten stort set findes i hele Sahmah-skiferens udbredelsesområde. Den er dog bedst udviklet i den nordlige del af udbredelsesområdet, hvor skiferen er fra Ordovicium til Nedre Silur. Der har eksiste- 


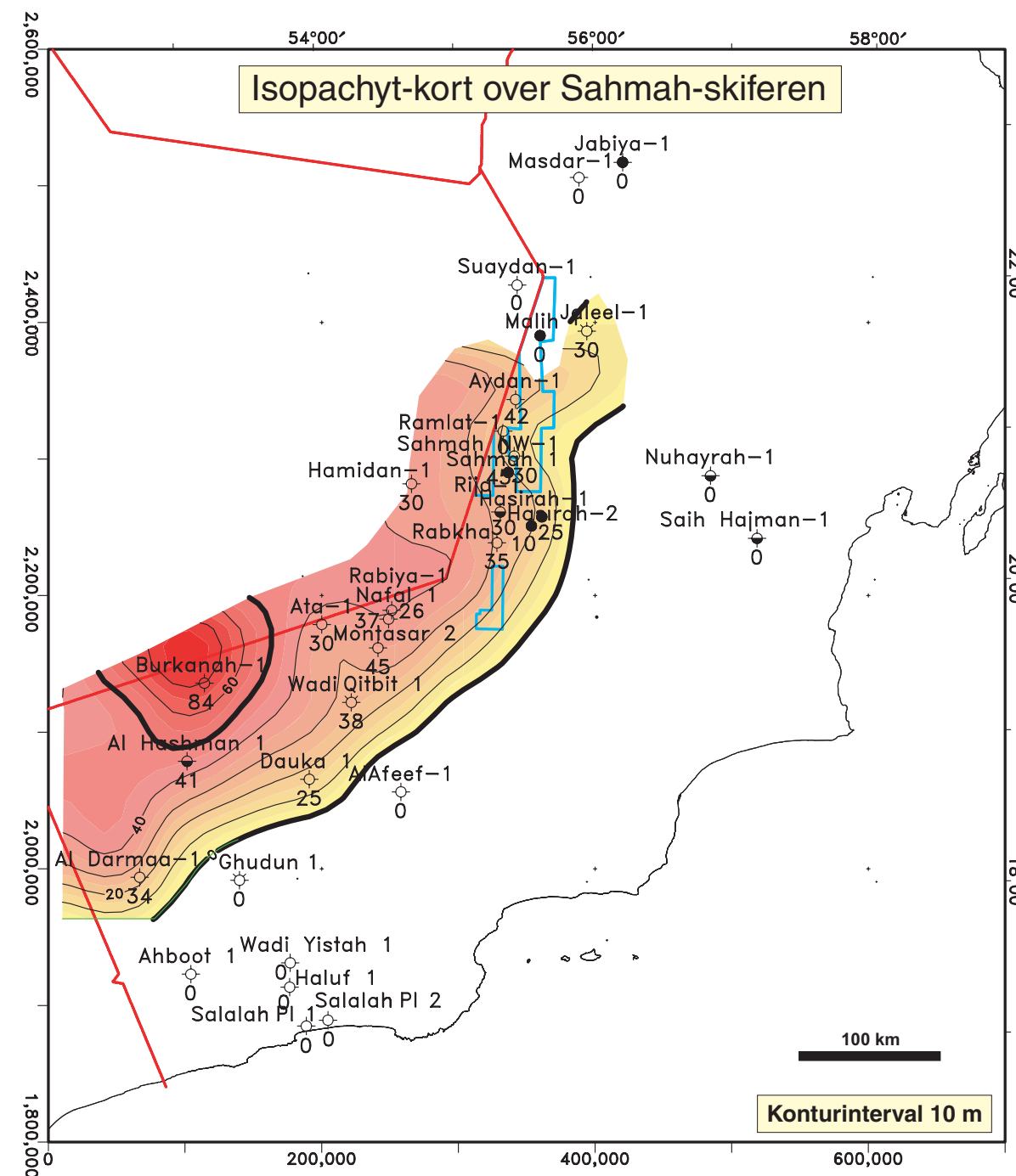

ret en længere periode med lav sedimentationsrate, hvorved det organiske materiale kunne koncentreres. Mod syd, hvor skiferen kun er af ordovicisk alder, var der en kortere periode med lav sedimentationsrate. GRloganomalierne er derfor dårligere udviklet mod syd.

\section{Kulbrintedannelsen og migration}

For de boringer, der har gennemboret kildebjergarten, konstrueres såkaldte "burial diagrams" (figuren nederst på denne side; der er her brugt det engelske ord, idet oversættelsen, begravelsesdiagram, lyder så dystert). Et sådant diagram viser, hvorledes de enkelte formationer er blevet begravet, opløftet og måske eroderet i tidens løb. Litologien for hver formation bestemmes og lægges ind i modellen. Parametrene for kildebjergarten bestemmes og indføres - ligeledes indføres TOC ("total organic content"), kinetiske egenskaber og type af organisk materiale (om det er en kildebjergart, der overvejende danner olie eller overvejende gas).

Modellen skal nu kalibreres. Der er to kalibreringsparametre, som almindeligvis bruges, temperatur og kildebjergartens modenhed.

Temperaturen er den temperatur, som er målt $i$ borehullet, og som relaterer til den geotermiske gradient. Det er temperaturen, der bestemmer omdannelseshastigheden for det organiske materiale, jo højere temperatur jo mere omdannelse. I denne forbindelse skal overfladetemperaturen bestemmes også tilbage i tiden. Overfladetemperaturen sammen med den geotermiske gradient bestemmer temperaturen i undergrunden. Endelig er det vigtigt at bestemme, hvorledes sedimentoverfladen har ligget i forhold til havoverfladen - med andre ord om der har været et dybt hav eller et højt bjerg.

Der er flere slags modenhedsmålinger, som kan anvendes. Vitrinit-reflektans ( $\mathrm{R}_{\mathrm{o}} \mathrm{i}$ $\%)$ er dog den mest benyttede og samtidigt den modenhedsparameter, som de andre modenhedsmålinger kalibreres til. Ved en $\mathrm{R}$ mellem $0,5 \%$ og $0,9 \%$ omdannes det organiske materiale til olie. Over $0,9 \%$ dannes stigende mængder gas og kondensat. Efterhånden krakkes olien ligeledes til gas. Ved en $\mathrm{R}_{\mathrm{o}}$ på $2 \%$ er der ikke meget kulbrintepotentiale tilbage i kildebjergarten.

Man indfører en værdi for "heat flow" ("heat flow" er et mål for den varme, der stiger op fra Jordens indre), typisk værdier mellem 30 og $100 \mathrm{~mW} / \mathrm{m}^{2}$. Man kan gøre det som en konstant værdi eller som en tidsvariabel. I området omkring Sahmah-skiferen har der ikke været en høj tektonisk aktivitet. Den rift, der ligger i Østoman har næppe påvirket området. Der er derfor valgt en konstant værdi. Heat flow-værdien ændres, indtil der er en god tilpasning mellem modelleret og målt temperatur og modenhedsprofilerne. Herefter er modellen færdig.

I det foreliggende eksempel er der brugt ca. 13 boringer til at måle variationen af mo- 


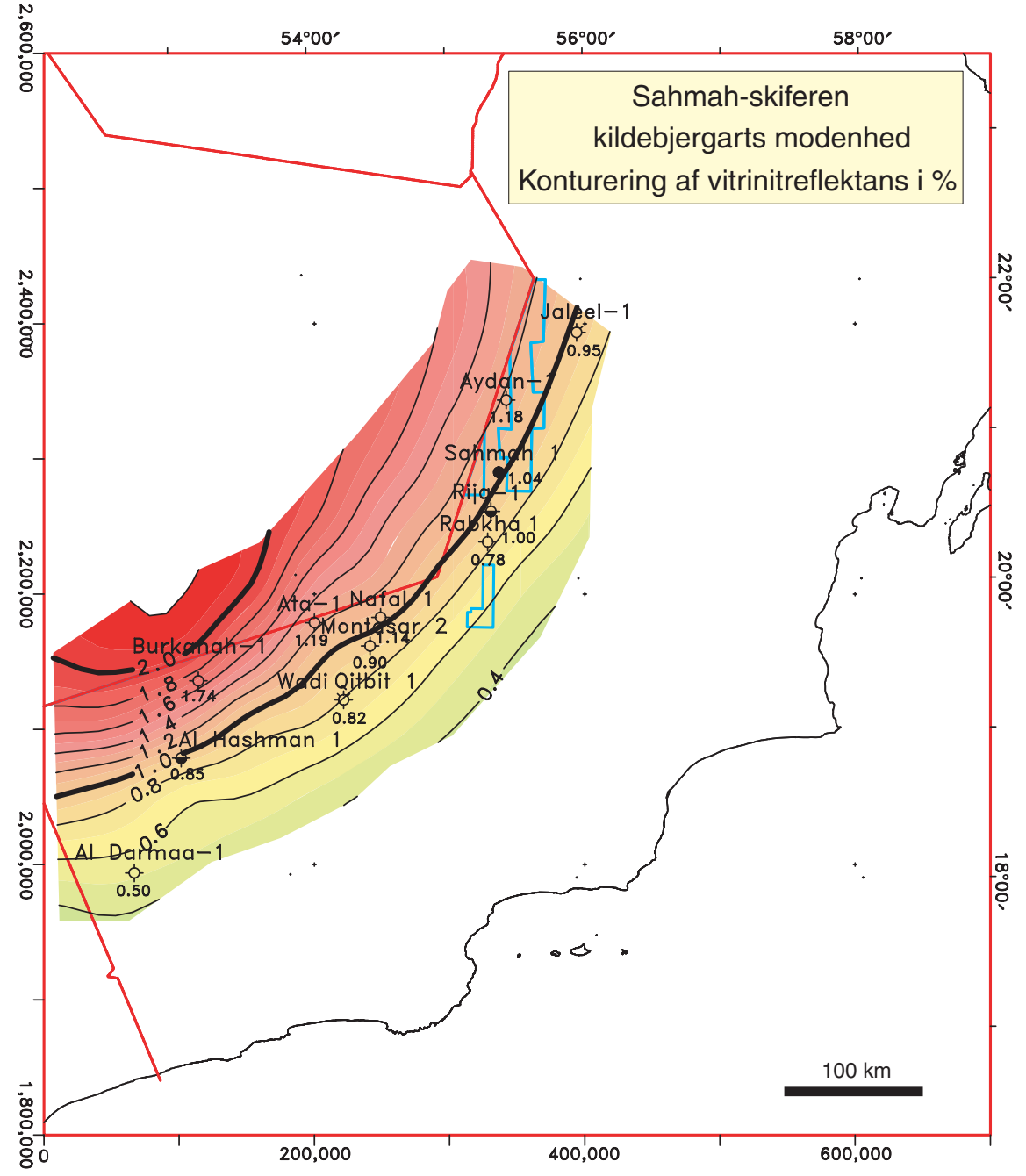

Modelleret Vitrinit-reflektans $i \%(R)$ for Sahmah-skiferen. (Grafik: Forfatteren) den Hercyniske Inkonformitet, kan olien flyde opad ind i Al Khlata Formationen. Da denne mest består af sand, fanges olien først i Gharif Formationen, hvor der findes skiferlag, som kan stoppe den videre færd.

Mod nord er den kraftigt eroderet $i$ et større område, og der er erosionsdale, måske gamle floddale eller gletschereroderede dale. Der er derfor et større område, hvor kildebjergarten ligger umiddelbart under den Hercyniske Inkonformitet, og hvor olien kan flyde opad og ind $i$ Gharif Formationen. I det sydlige Oman, hvor en langt større del af Sahmah Formationen er bevaret, er det kun den underliggende Hasirah-sandsten, der modtog den dannede olie. Som nævnt dannedes olien dér, før der var dannet nogle strukturer, hvor olien kunne fanges. Der er derfor endnu ikke fundet forekomster af olie i Hasirah Formationen i Sydoman, men flere af boringerne har dog spor af olie og gas, som viser, at processen er foregået. Derimod findes der flere mindre oliefelter i det centrale Oman, hvor olien stammer fra Sahmah-skiferen. Sahmah-feltet er det største af disse.

Denne artikel er baseret på en artikel af undertegnede udgivet i GeoArabia, Vol. 9, No. 3, 2004 og hedder The Sahmah Formation of Oman: Exploration implications for the Rub' Al-Khali Basin. Denne artikel og artiklen $i$ GeoArabia blev udgivet med tilladelse fra Morsk Olie og Gas AS. Jeg vil gerne benytte lejligheden til at takke for tilladelsen samt gode kollegers konstruktive kommentarer. denheden af Sahmah-skiferen i det område, hvor den forekommer. Burial-diagrammet på modstående side for Burkanah-1-boringen er et eksempel på en 1D-model. Burkanah-1boringen ligger i det sydlige Oman.

\section{Resultatet af modelleringen}

Efter at hver af boringerne er blevet modelleret, kontureres modenheden af skiferen (figuren ovenfor). Kortet viser, at modenheden er lavest mod syd, hvor skiferen også er mindst begravet, og stiger så ind imod bassinets midte.

Det er nu vigtigt at vurdere, hvornår og hvor kulbrinterne dannes. I syd er Sahmahskiferen knap nok begyndt at danne kulbrinter i dag, mens kulbrinte-dannelsen $\mathrm{i}$ Burkanah-1-boringen allerede begyndte $i$ Kridttiden. Mod nord ved Sahmah-1-boringen begyndte oliedannelsen $\mathrm{i}$ begyndelsen af Tertiær.

Da den rigeste kildebjergart findes i bunden af Sahmah-skiferen, flyder den dannede olie først ind $i$ den underliggende sandsten $i$ Hasirah Formationen og derefter mod lavere niveauer (figuren til højre). Kun i kanten af Sahmah Formationens udbredelse, hvor den er eroderet næsten helt bort, og hvor kildebjergarten derfor ligger umiddelbart under

\section{Konceptuel migrationsmodel for Sahmah-skifer-kildebjergarten}

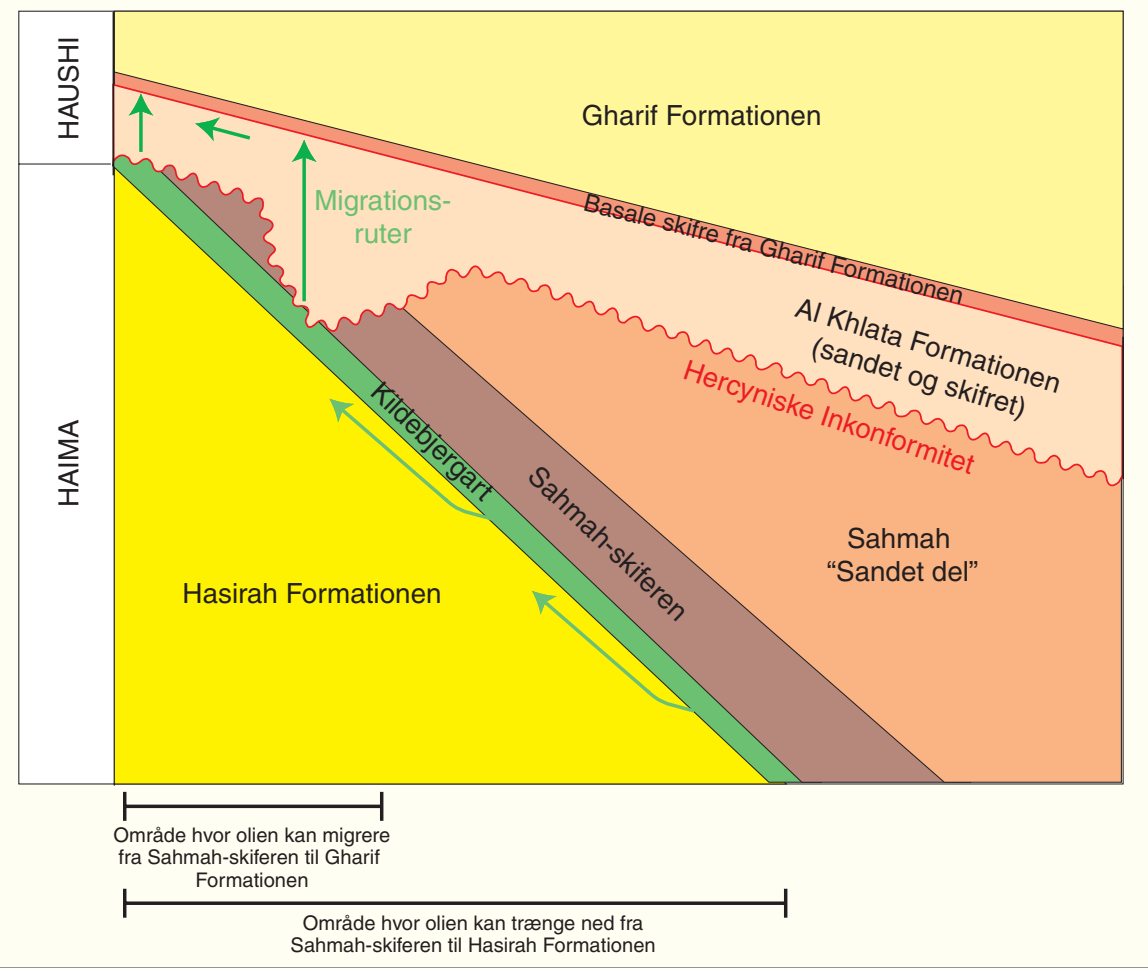

Konceptuel migrationsmodel for Sahmah-skiferens petroleumssystem. (Grafik: Forfatteren) 